\title{
Strategy to improve the competitiveness of National Indonesian Ship Building Industry
}

\author{
Case study of PAL Shipyard \\ Pratama Akbar 1,a,*, and Raja Oloan Saut Gurning 1,b \\ ${ }^{1}$ Department of Marine Engineering Department, Institute Technology Sepuluh November, \\ Surabaya, Indonesia \\ a.rabka.pratama@gmail.com, b.sautgurning@gmail.com \\ *corresponding author
}

Keywords: Indonesian Ship Building Industry, Marine Operation, PAL Shipyard Industries, Shipyards, Shipping, Shipyard Industry.

Abstract: the history of maritime navigation and maritime commerce is related to the beginning of human civilization. The vessel is a kinds of transportation, based on the size (capacity also dimension) as good as characteristics of the technic and technology also the ocean as the delivery lane, is a transport for goods in extra quantities, bridging ports around the earth. A shipping manufacture was an economical also industry task which contains shipyard, boat distribution also vessel repair. Project Development was realized below a supervision from its Master Project or Manager Project. Stages at Development, realization also assurance at development project that taking location within the shipyard industry are define project life (cycle period). Work life could described with the timing in where an operation generates profit also makes expenses. Judging base on the industry's character, the shipping industry is defined as industrial strategy also had the effect for working layers at wide areas and encourages growth for its supporting industries. An importance of enhancing the strategy for the contribution of the National Shipping Ship Industry economically, it is necessary to increase the competitiveness so that the business or venture industry can grow in a long-term and sustainable manner. The competitiveness improvement indicator can be measured from Quality, Cost, Delivery Time, and Environmentally Friendly Safety Health for the life of the project. One of the most important aspects that affect the achievement of the improvement of competitiveness is the Mastery of Technology and Human Resources. This Journal paper is directed to efforts and improve competitiveness on Technology Mastery Strategy and Company Capacity Resource of Development in the Shipping Industry. 


\section{Introduction}

The first stage, which now exists is capable of building and repairing large ships. Development Time and Delivery Time are important competitiveness factors. Development period was usually calculated with a first construction material progress until submission. There are several factors that become benchmarks, among others are Management Aspect, Productivity / Production Cycle, Cost Control and Load Reduction, Risk Management, Diversification, Financial Risk and Government Policy. The shipping project from the perspective of the shipyard, for example consideration from the manufacture include operation-based process and desire to explain a necessary for an operation period, as good as a technological influences on different stages of the project. The established methodology required to estimate vessel body also project expenses was more often according to criteria also hull information of the 1960s. With dimensional design, storage limitation was defined together withal composition construction material required. A previous approach assumes that steel construction is little obtain for any kind odd brand new matter just like alum. or composite materials.

An ocean (covering seventy point eight percent from sum of all surface of the world) was exclude the major transport route and include the open lane which exclude require high-priced facility modals. The condition affect seagoing transportation very economical. The ship owner bore most of the activity. The term owner of the ship, which is used for decide the independent maritime company at marine transportation and derived by a marine rule that describe the physical / law entity that utilize ships like a facility at marine vehicle for persons also cargo.

A vessel for a parts from transportation, judging by the proportion (capacity also dimension) as good as the characteristic of technic also technology also an ocean for the delivery lane, is the most reasonable means to transport for maximum quantities for cargos bridging ports around an earth. A shipping manufacture was a reasonable also industry task which contains shipyard, boat distribution also vessel repair. A major specification at a shipyard manufacture located on a data if the vessel was include information the combine from various goods, unfinished goods also raw products manufactured from some other companies. A dockyard's job was to combine an existing raw products also unfinished goods, / under important problem, do the final process / collect a parts / fit products and make a finish project - a vessel. There are few branches of industry that affect, directly or indirectly and in conditions during shipbuilding.Be advised that papers in a technically unsuitable form will be returned for retyping. After returned the manuscript must be appropriately modified.

\section{Literature Review}

a. Globalization of Indonesian shipyards

In these period of trade globalization, nations are develop considering the competitiveness of the industries on overall trades. Manufacture competition is characterized by several important factors that interact with each other. Thereof, this is important to Indonesian shipyards for appraise the shipyard expenses, benchmark the competition position also how to get action for substantiate the competitiveness. Proposing production expenses was an important development place. Because competition was a relational draft, these journal collates Indonesia with the main competitor. Articles are organized for complies: A remain part presents a cost component for boatbuilding. In developing countries, the lack of systematic research on employment relationships and the rise of shipbuilding is very influential. However, the competition in the field is getting tighter. Parts for a management prudence steps are: setting goals, set special purposes, practicing programs behaviors, also examining, approving also reviewing doings as well as targets. These journal desires for define a great effort for reconstruct a Indonesian trade, the resources of the company and then look how 
this construction refines affect a sailing also harbor areas of Indonesia. As the turn out, Indonesian shipbuilders are again searching for potential trades. The technology transfer-argument was a good research to provides the definition for a results the ship agreements on Indonesian shipbuilders since 1959 until 1997.

b. Human Resource Management Dispute

Workers outside the contract or outsource part-time employment is a common practice in the company. Globalization is considered inherently different from the nature of independent Small Medium Enterprises outside market share, especially among others for, rationalizing the world economy in the form of its function efficiently with an optimal cost reduction strategy.

c. Deficiency of Company Authority

This first section will highlight the need for further regulation in terms of viability of the shipyard's working relationship. It will then focus on concerns about trade regulation as an obstacle to better business performance.

d. Under the rules of employment

The National Shipyard holds that the government behaves like a high-ranking officer and seems to be the enemy of the company. Conflict of interest is another cause of concern. The conflict was reportedly derived from criticisms of what was dubbed a corporate takeover. That is, successful entrepreneurs sometimes join political parties and they become influential bureaucrats, parliamentarians, cabinet ministers, if not heads of state, they can certainly do it (Monbiot, 2001).

e. Strategy of Human Resources Management

A number of Human Resources strategies are introduced in the company to stay alive and perform better. These include the establishment of managerial structures, adjusted work-life balance, and strategic retention for skills constraints, trade union organizations to increase commitment, individual grievance resolution, teamwork, reciprocity, and dynamic work also mobile employment.

\section{Case Data Methodology}

Our data is about Indonesian shipyard order book which comes from the final edition of Marine Engineering publication. I. Freight with cargo, Ferry, bearer, also person-load ship. II. Coarse Cargo consists dry cargo carriers. III. Oil Carriers consist product tanker, LPG vessels, synthetic oil carriers also sulfur tanker transporters. IV. Merchant Vessels shall consist every not-navy ships none protected from I. - III. V. Carrier includes the force carrier, airfare shippers also the polyfunctional carrier. VI. Development consists marine supervision, surveying, and oceanography, deep inside ocean investigation, companion recitation and study ships. VII. Sub Marines consist attacks submarine also tactical torpedo submarines. VIII. Surveillance battles consist rocket disturbers, fast surveillance boats, intruders, torpedo submarines, rocket explorers, amphibians' warships, amphibious attack vessels, amphibians center vessel, frigates, guide rocket frigates, explorers, missile cruisers and rocket ships also sea tugs. IX. Other Reign Vessels consist every naval ships none included in V-VIII.

At additional of cost, trade stock was a necessary part for the power of shipyard's competitiveness. One of the limitations for these competition research was this trade stock isn't a stand-alone indication.

a. Impact of subsidies

There are several probabilities. This is entirely forwarded for vessel buyers at a document for a proportional fitting price. This is fully restrained from a shipyard owner also occurs on rumored proceeds also stockowner bonuses. This is surpass on the shipyard employers, between on a 
document from high true reward for a similar amount of employers / the similar true revenues but with much employers than they should worked. Several coalition from entire of an over.

b. Other forms of assistance available for ship building

- Assistance to development also research can become ratified at adaptation under an association demarcation to development also research assistance.

- The reconstruction assistance, required to construction adaptation also enhancement of competition, can become certified as long as it accepts under an association rules at nation help to save also restructure the company as well.

- The investment assistance of newness, presented at $20^{\text {th }}$ century, is commonly not aboveboard in another areas, which until about twenty percent from an expenses relative with an inventive piece from operation costs.

- PT. PAL Shipyard Indonesia.

- Shelter assistance, which includes social assistance to reduce the impact of adjustments and social assistance to protect any common expenses caused from sum / patch closure, probably become certified in accordance.

- Workers' Assistance, provided for occupation also tenancy for workers with disabilities also unable persons, providing that they comply with other Economic Cooperation regulations of the Economic Cooperation Treaty for the State Employment Assistance center.

- Assistance in the format for nation-backed charge infrastructures and given for nation also not-nation ship owners to build ships that can be provided in accordance with the requirements of the Organization for Economic Cooperation and Development 1998 in Exportation Loans for Vessels.

- Assistance provided on a format for research assist for development nations are able because of its kind for assistance are allowed below an Economic and Development Cooperation Organization Regulations 1998 in Rules of Approved Exportation Credit also Area Receipting in Exportation Loans.

- Sectorial investment assistance to upgrade or modernize the existing shipyard in order for develop a fecundity for existent assemblies and be authorized as long as the shipyard is in a qualified area and that such assistance are restricted for help expense as determined at an Association Rules at applicable sectorial assistance.

c. Measuring Ship Expenses

At these journal, 3 parts are served for estimate the cost of ship building: labor, steel and ship equipment.

The method used to estimate vessel structure also operation expenses by Harry Benford, the doctor from marine engineering also naval architecture in an Michigan University also dating since year 1960. But His oncoming was come from the assumption that draft has grown increasingly invalid (Benford, 1993).

$$
C=U L C+S+E
$$

Where $C$ represents the cost of shipbuilding, ULC represents labor cost, $\mathrm{S}$ reflects steel cost and E reflects the cost for vessel equipment.

d. Method

- The company under study is located in East Java, Surabaya where most of the shipyards and many small workshops there have been restructured.

- That is expected this wider information sets would authorized to more credible estimation. 
- A common technical is designed as the 1st-demand purpose for a Producer Price Index also the 3rd demand purpose for DWT:

- New build Expense $=\mathrm{A}[\mathrm{PPI}]+\mathrm{B}[\mathrm{DWT}]+\mathrm{C}[\mathrm{DWT}]^{2}+\mathrm{D}[\mathrm{DWT}]^{3}(2)$

- Employment and productivity trends. This is profitable for the shipyard, but if it is not competitive, it is a cost, because it will lead to the purchase of the vessel at a higher cost than can be obtained from elsewhere. Recent reports indicate that the shipyard with low productivity trends is under threat of closure.

- Performance indicators benchmark. Shipbuilder competence, shown from region, assembly region also module move rate, has an impact on productivity and building time index.

- The final index [Ftech] is an common for a value of a working group. Working group considered for the evaluation of shipbuilding technology are as follows: Assembly also Construction, Fabrication and Equipment, process also product manufacturing, Management also Organization Process.

- Shipyard operations include with a launch stage, a materialization operation stage also an assurance stage.

- Overture rite includes with an ensuing major stages: investigation argument - tutor, determination for mend the overture, preparative to origin collaboration, preparative from overture parts, preparative from other overture weathers, 1st estimation also rate for overture, proffer merger, preparative for another overture, proffer dispatch, coherence at problem for local preference, end overture, signature for the covenant.

- Materialization includes: signed overture, preparative to operation materialization, initialing an operation materialization preparative, launch the project.

- Guarantee includes: operation conclusion, operation realization analysis also assurance term preparative, receiving assurance term also consequence for quality.

- A shipbuilding enterprise was the no exception. At a subsequent segment, this elements were described base on a creator expertise at a shipyard manufacture on Indonesia, where any a most portable shipyards on a nation is.

Outer factorize comes from: Low building prices, Exchange rate. Inflation. New taxes. Supply delay. Deficient power supply.

e. Shipyard Operation

The shipyard operation was the structured programmed operation, given an event those the ship was establish at a particular shipyard also buyer research program. The final destination and objectives of the object have been determined at the stage of the project launch, prior to itself materialization. An objective was for achieve the strategically purposes from a shipbuilder research program thru a realization of operation objects as good as for achieve a buyer's purposes thru a materialization for an objectives of the operation objective extortion.

The timing for shipyard operation realization is;

$\mathrm{Tlb}=$ lay for base to the novelty vessel

Tsor $=\mathrm{Tlb}+\mathrm{Tlv}+\mathrm{Tse}, \mathrm{Tlv}=$ launching of a vessel, Tse $=$ ship equipping.

The duration of the shipping project period (cycle time) is equal to:

Tsplt $=$ shipping project launching time, Tspp $=$ Tsplt + Tsot + Tsoat

Tsot $=$ shipyard operation term, Tsoat $=$ shipyard operation assurance term 
Shipbuilding as a maritime subsystem also manufacture scheme have an important piece so could become look through an ensuing event:

Supplying a world trade fleet with new means of transportation, Supplying naval by new vessels, establishing trades infrastructures also enabling a research for marine trades actions also important trades to marine mobilization, affecting a need also offer for load also goods transport rates, affecting global ship rates, standards and payment terms, favoring a research for a material manufacture also any chapters of industry, floatation unit construction, fish fleets ship, marine research vessels also submarines, yachts, speedboats also any ships affecting a country collate for payouts thru vessel imports also exports for proliferation materials, terms also sub terms of the major amount for employees on the shipyard, Affecting multinational mutual approvals.

f. Unit of Worker Expenses

Salaries is usually settled at native currency also the value on Rupiah IDR (US Dollar) fluctuates by a change tariff of its currency (2003, Bertram). That are commonly issued so change tariff degeneration set down a cost of native cash on $\$$ also whereas. It should be noted so salaries stand doesn't define labor expenses: that are as well important for contemplate labor fecundity. On otherwise, salaries shall become adapt to a fecundity of labor on every nation. Compensation Gross Tonnage was deliberated at vessel kind also dimension also its multinational constant.

$\mathrm{UWE}=$ MMS / PRO

Wherein AIW was a Mean Manufacture Salary (Rupiah IDR [U.S. Dollar] / Man Hour) also PRO was the productivity of vessel construction (Compensation Gross Tonnage/Man Hour).

g. Material Component Cost

Ship equipment cost is measured by:

$$
\begin{gathered}
\mathrm{E}=(\text { Expense on ship equipment }) /(\text { Shipbuilding delivery }) \\
=(\text { Production turnover }- \text { Export }+ \text { Import }) /(\text { Shipbuilding delivery }) \\
\text { Reintroduction of subsidized operations of the Shipping Industry }
\end{gathered}
$$

Character for shipbuilding outcome, also its fecundity comes from the wide variety of ships manufactured on global dockyards, ranging since great magnificent cruises, occupant ferries also load, raw tankers also proceeds, dried cargo carriers for any dimensions also containers, loaders \& special ships.

The outcome on that area was calculated by Compensation Rough Tonnage (CRT), on the arranged for create knowing comparisons on different types for ships builder. [Stop ford] identify 4 major elements to create kind a comparison complex.

- Differential vessel kinds prosecute diverse numbers for duty on procreation; in comparison a labor need for make the excursion ship was much complicated with this requirement for build dried collector cargo vessels, thus that the complacency adjuvant was used for every ship sort; Otherworld, calculating the results of various kinds of shipyards is meaningless if the shipyard produces different ship type proportions.

- Some shipyards have different measurements to labor agreement outside of different offices, thus a size for labors working exactly to 'construction dock' would reduce a number for labors joined at building a ship.

- Shipyard might has the mixed contract for military also civil voyages. 


\section{Result}

The That are too any basically also this interpret this on a jury's viewpoint, mart rate digression wasn't big adequate for being sign. This program was created for increase shipyard trade perpetuity on the amount actions.

\subsection{Determining the Goal of Shipping Projects}

The aspect shown by the Figure 1 should be considered. This aspect is respected on manners for define also realizing the shipyard project as good as state goals. A project goal determines a priority for one or other aspect when determining goals. On modes for materialization, shall being optimal between one angle with the other.

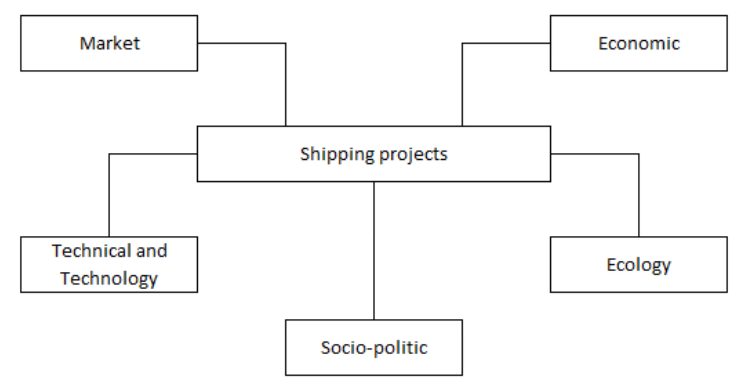

Figure 1: Aspect of the Shipping Project

\subsection{Productivity}

On new classical shortly-time margin expense rating, that are logic for rate on the degree so doesn't protect a whole sum expenses for the agreement in case thereat was salvage competence also when therein are in less the potent finance collaboration has been create, etc. In case an agreement protects a directly varied expenses also creates the collaboration pertaining expenses. While that aren't the length-time continue tactic, which are the logic terse-time 1.

a. Compare the development of shipbuilding costs.evaluate the competitiveness on the basis of shipbuilding costs and market share. As noted, the total actual change (c) is the sum of these three effects. A good indicator of a yard's overall performance is the sum of vessel mix and competitive effects $(v m+c e)$. Thus, the shipyards in are ranked by total share shift, or the sum of proportional shift and differential shift. The results of our dynamic shift-share analysis for the some periods.

b. Estimation of a single model including all ship types allows available degrees of freedom afforded by the large data set to be used to the fullest advantage. Each type is distinguished in the data set by dummy variables for each type: dry bulk carriers, containerships, tankers, LPG tankers, and LNG tankers. GC ships are also included in the data set and are distinguished from other types by the absence of a dummy set to one for that type. Omitting the dummy for onecategory is a standard and necessary practice to avoid a non-invertible, exactly singular matrix that would make it impossible to estimate regression coefficients. The coefficient of Producer Price Index is positive and significant.

\subsection{Ramifications}

Interestingly, intercepts are always large and negative, particularly considering that they are dimensioned in millions of dollars. One implausibility of the second order, non-linear cost function for dry bulk carriers is that cost declines (though very slightly) between about 70,000 and 120,000 tons, suggesting that a linear specification may be preferable. 
The third order coefficient of tonnage is negative and significant, indicating that scale economies are present, but the third-order term is positive and significant, indicating scale economies are not unlimited. The dummy variable coefficients are also all significant and serve to distinguish the different types of ship, which have systematically different costs. LNG tankers are dramatically more expensive than other types ships. Bulk carriers, tankers, and containerships cost less. Containership cost is not much less than GC carriers, though the small difference is statistically significant. LNG tankers are the most expensive ship type, dry bulk carriers the cheapest to build, followed by ordinary tankers.

Corporations are required to produce combined financial statements from the beginning of fiscal year 1999 in order to assess the extremely complicated web of internal - group transactions inside.

\subsection{Transparency and accountability}

There are some 140 yards still active in either ship construction or repair/conversion, despite the loss of market share to yards. Forty of these yards are in the global market for large sea-going vessels. Despite the record levels of production, profitability of the yards.

Table 1: Foreign direct investment in asia (billion us\$).

\begin{tabular}{|l|l|l|l|}
\hline \multirow{2}{*}{ Table Head } & \multicolumn{3}{|c|}{ Period } \\
\cline { 2 - 4 } & $\mathbf{1 9 9 6}$ & $\mathbf{1 9 9 7}$ & $\mathbf{1 9 9 8}$ \\
\hline Country & FDI & FDI & FDI \\
\hline Korea & 2.3 & 2.8 & 5.1 \\
\hline Thailand & 2.3 & 3.7 & 7 \\
\hline Philippines & 1.5 & 1.1 & 1 \\
\hline Indonesia & 6.2 & 4.7 & -1.3 \\
\hline Malaysia & 5.1 & 5.1 & 3.6 \\
\hline Total & 17.5 & 17.5 & 15.4 \\
\hline
\end{tabular}

Source of a UNCTAD. (1999).

Annual average value.

The Foreign Direct Investment (FDI) climate in Indonesia was decreased in May and October 1998 through Monetary Crisis (see Table 1).

\subsection{Phase of Shipping Projects from the Perspective of Shipping}

Figure 2 illustrates the hierarchy adopted for assessing the shipbuilding industrial environment, including the weights assigned to each criterion.

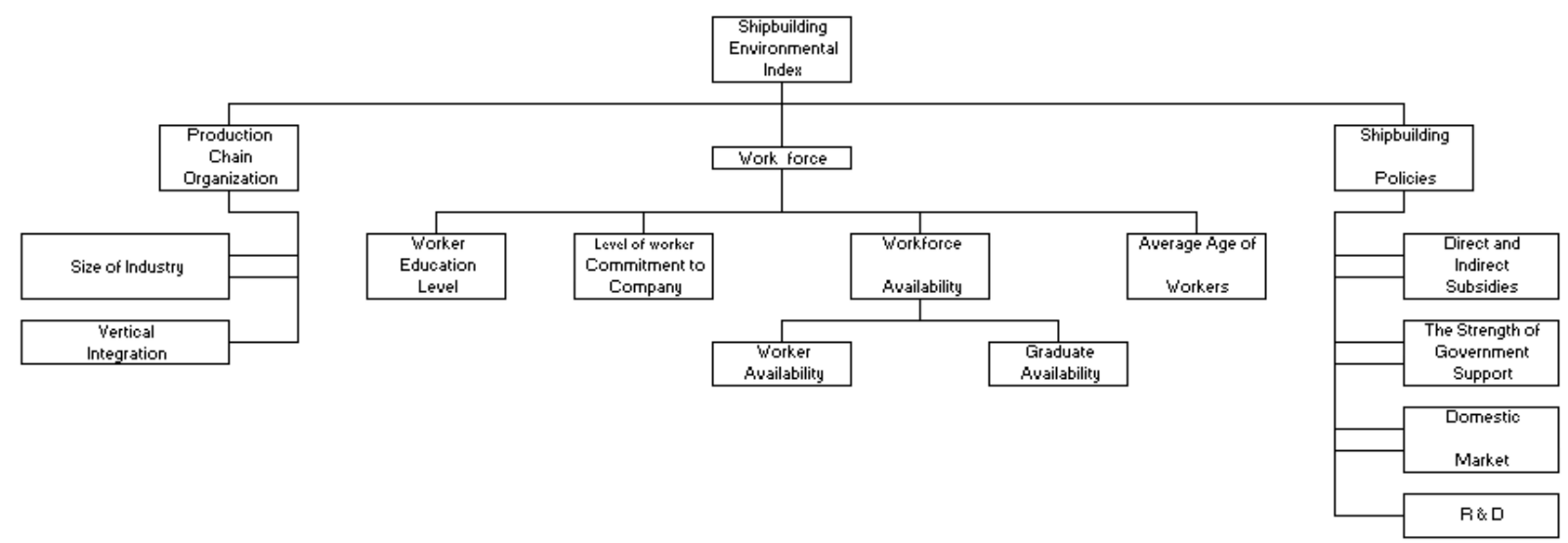

Figure 2: Analytical Hierarchy Process for the Shipyard Industry 
From a Shipyard's perspective, shipping project lifetime can be seen as a project having direct effects as shown in Figure 3.

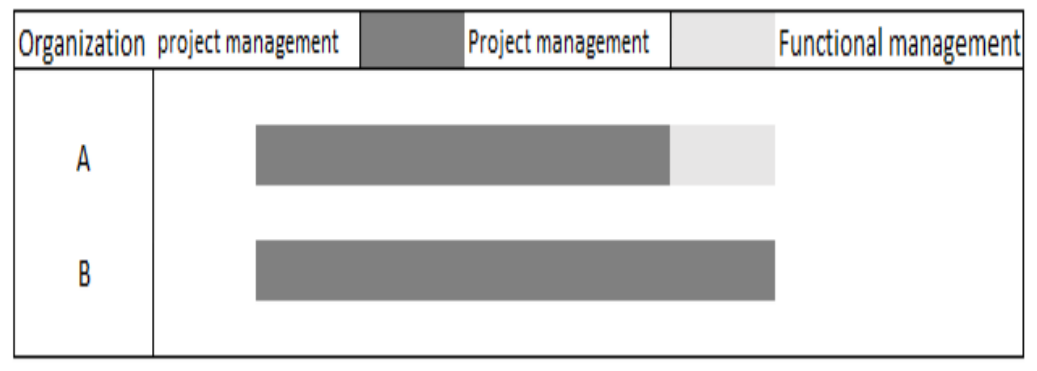

Figure 3: Project management during the lifecycle of the shipping project

A quality defined shipping project lifetime demands a project approach. The shipyard gains competitive advantage, economic stability and development prospect. Shipbuilding as a subsystem of the maritime and industrial system has a significant part that can be seen from the following facts.

Companies are required to create a combined financial report from the beginning of the fiscal year to assess the complex network of internal transaction groups within it. Listed below are some suggestions, which can also help alleviate some of the issues discussed earlier:

Encourage the production of shipbuilding equipment that can enable greater control of supply of logistics supply and supply chain equipment, which may reduce risks in delivery shipbuilding delays; Provide greater support to the domestic market, especially small ships that can create resistance to fluctuating demands on the international market; Investing in research and development, and specialist ship types by refining existing methods, experimenting on new products, enabling innovation and building new market niches; and Growing excellence in training and education, it will improve the labor force standards that will ultimately improve industry standards and overall competitiveness.

A further step in this research effort should be the development of a methodology for follow-up programs aimed at technological advancement and development of shipyard building facilities.

Shipping projects are complex projects when considered from a technical, technological, organizational, economic, ecological and legal aspect. This is why, from a shipyard's perspective, i.e. perspective of a project driven production company, a quality project lifetime calls for a project. Suggest a framework for assessing shipping costs and their impact on the competitiveness of Indonesia's shipping industry. Estimated cost and competitiveness can be used by multiple shipyards to control production costs and when making shipbuilding offers. Insofar as it concerns the shipping and port sectors, the above principles have an impact on the opposite and profitable. The main advantage of dynamic analysis is in its ability to record fluctuations between the initial and final years, which static analysis cannot be accounted for. This dock works to improve material flow, accuracy control, and planning (time manner).

\section{Acknowledgements}

Thank to Raja Oloan Saut Gurning, Mr. Tjahyono Yudo, Joza Yosa Emerald and any anonymous referee, for helpful comments and suggestions. I retain responsibility for errors or shortcomings soon. 


\section{References}

[1] 1st National Marine Industries Forum, Hotel Istana, South Korea and Malaysia Shipbuilding Industry Historical and Technical Comparison, 23 March 2010.

[2] A. Bistricic, "Shipbuilding Projects from a ShipYard's Perspective and the Role of the Bank in the Project LifeTime", Management, Vol. 12, 2007, 1, pp. 101-111.

[3] Bertram, V., "Strategic control productivity and other competitiveness parameters". Proceedings of the Institution of Mechanical Engineers, Part M: Journal of Engineering for the Maritime Environment 217(2): 61-70, (2003).

[4] EC, Defining the future of the European Shipbuilding and Repair Industry:- Competitiveness through excellence. COM(213) 717 final, European Commission, Brussels, 2003, LeaderSHIP 2015.

[5] EC, Seventh Report from the Commission to the Council on the Situation in World Shipbuilding. COM (232) final, European Community, Brussels, p. 3, footnote 4, 2003.

[6] Floriano C. M. Pires Jr. \& T. Lamb, "Establishing performance targets for shipbuilding policies", Maritime Policy \& Management, 35:5, 491-502, October 2008.

[7] Ivana Mikačić, Željana Dulčić, "Implementation of the Process Approach and Business Process Management Concept in Croatian Shipyards", Management, Knowledge and Learning International Conference, 2012.

[8] K. Muthuchelvi Thangam and D. Sureshkumar, "Competitiveness of Indian Ship Building Industry", International Journal of Innovative Research \& Development, ISSN 2278 - 0211, Volume 04 Issue 07, July, 2015.

[9] Kenneth A. Potocki and Richard C. Brocato, "A System of Management for Organizational Improvement", Johns Hopkins APL Technical Digest, Volume 16, Number 4, 1995.

[10] KING, J., New directions in shipbuilding policy. Marine Policy, 23(3), 191-205, 1999.

[11] Lee Hyun, Strategies for improving the competitiveness of the Korean shipbuilding industry : Case study of Hyundai Heavy Industries, The Maritime Commons: Digital Repository of the World Maritime University, World Maritime University Dissertations, 2015.

[12] Maritime Administration Department of Defense, Ways to Increase U.S. Shipbuilding Productivity, Report to the Congress, Sept. 23, 1976.

[13] OECD, Agreement respecting normal competitive conditions in the commercial shipbuilding and repair industry, http://www.oecd.org/, 1994.

[14] OECD, Arrangement on Guidelines for Officially Supported Export Credits, http://www.oecd.org, 2002.

[15] Philippe Rigo, Djani Dundara, J-L Guillaume-Combecave, Stanislav Domagallo, Alan Klanac, Frank Roland, Osman Turan, Vedran Zanic, Amirouche Amrane, Adrian Constantinescu, "Improve-Design of Improved and Competitive Products using an Integrated Decision Support System for Ship Production and Operation" unpublished.

[16] Rima Mickeviciene, Global Competition in Shipbuilding: Trends and Challenges for Europe, Klaipeda University Lithuania, The Economic Geography of Globalization, www.intechopen.com

[17] Soon-Ick Hong, "Ship Building and Yard Management", October 8, 2015, unpublished.

[18] Stopford, M., Maritime Economics (London: Taylor, Routledge \& Francis), 1997.

[19] Stopford, M., World Shipbuilding, www.clarksonresearch.com/ acatalog/smm.pdf\#search1/4'stopford\%20hamburg\%20shipbuilding, 2004.

[20] Tae-Woo Lee, "Restructuring of the economy and its impacts on the Korean maritime industry", Maritime Policy \& Management, 26:4, 311-325, (1999). 